\title{
Spawning of anchovy Engraulis encrasicolus in the Northwestern Mediterranean relative to hydrographic features in the region
}

\author{
Isabel Palomera \\ Institut de Ciències del Mar, Passeig Nacional s/n, E-08039 Barcelona, Spain
}

\begin{abstract}
The present study furnishes conclusive evidence for the existence of latitudinal differences in the duration of anchovy spawning related to temperature cycle and hydrographic features; 2 main spawning areas were found, one off northern and another off southern Catalonia (NW Mediterranean, NE Spain). Total egg production was similar in the 2 spawning areas and even somewhat higher in the northern area, where the spawning cycle was shorter (ca $2 \mathrm{mo}$ ). The areas of highest egg abundance were located relatively far offshore, between 10 and 30 miles from the coast, spanning a very broad range of bottom depths, from 50 to $1000 \mathrm{~m}$. The presence of a shelf-slope front of variable intensity running along the entire coast (Font et al. 1988) suggests that anchovy take advantage of the productivity associated with the front for reproductive purposes, particularly since the front is the most important enrichment phenomenon in the region during summer, the time of maximum spawning (Estrada \& Margalef 1988). In addition, the distribution of spawning activity brings to light its association with the zones of influence of the outflows of 2 large rivers, the Rhone and the Ebro. On the whole, the reproductive behaviour of Engraulis encrasicolus in the Northwestern Mediterranean takes advantage of the most favourable conditions to ensure the success of early life stages in a region in which enrichment phenomena are more limited than those described for other clupeoid species.
\end{abstract}

\section{INTRODUCTION}

The most abundant clupeoids off the coast of Catalonia (NW Mediterranean, NE Spain) are sardine Sardina pilchardus and anchovy Engraulis encrasicholus, which are the basis for the pelagic fishery in the region. These 2 species account for $60 \%$ of commercial catches, and although sardine makes up the larger share, fishing pressure is heavier on anchovy because of the higher prices brought by this species. The proportion of anchovy in the catches rose from 1965 (Larrañeta 1981) as catches of both species increased. Beginning in 1980, however, catches underwent a significant decline, especially those of anchovy, which yielded $15776 \mathrm{t}$ in 1980 but only $5066 \mathrm{t}$ in 1985 , although the stock is presently in a recovery phase.

Engraulis encrasicholus is widely distributed in the Northeast Atlantic and Mediterranean and adjacent seas (Reid 1967), and the species inhabits areas with very different environmental features, i.e. areas with high productivity (e.g. the Canary Current region), areas with warm waters and moderately high productivity, and areas with low productivity and extreme conditions (e.g. the Black Sea). Its distribution range includes bays, lagoons, and estuaries. Nevertheless, there have not been many studies on the species, as pointed out in the review by Blaxter \& Hunter (1982). In the past $10 \mathrm{yr}$ there have been important contributions on anchovy eggs and larvae by Regner (1985) for the Adriatic and Ré (1987) for the Mira estuary in Portugal. Recently some studies designed to apply the Egg Production Method in the Bay of Biscay have been made (Motos \& Santiago 1990).

The spawning behaviour of anchovy in the Western Mediterranean was described by Fage (1935), who suggested that adults came inshore to spawn. Andreu \& Rodríguez Roda (1951) and Bas \& Morales (1954) confirmed these findings off Catalonia and postulated the existence of 2 spawning stocks, one consisting of age $2+$ individuals at the start and height of the spawning season and the other consisting of younger mature 1-yr-olds at the end of the spawning season. 
Conversely, Suau (1979) suggested that anchovy migrated towards deeper waters during the spawning season.

In view of the limited and sometimes contradictory information on the spawning ecology of Engraulis encrasicholus in the Western Mediterranean and the importance of anchovy in the fishery off Catalonia, the object of this study was to investigate the spatiotemporal distribution of spawning in relation to the environmental features in the region.

\section{STUDY AREA}

The topography of the continental shelf off Catalonia is highly variable. The northern part of the region is characterized by 3 submarine canyons that approach the coast to within a few miles; between the canyons the shelf is $40 \mathrm{~km}$ wide. In the central part of the region the shelf narrows to the Sant Jordi Gulf, after which it broadens out to $60 \mathrm{~km}$ opposite the Ebro River delta in the southern part of the region (Fig. 1). The inflow from the Rhône River (north of Cape Creus; Fig. 1) over the shelf in the Golfe du Lion is one of the most important sources of inland waters off the coast of Catalonia (Castellón et al. 1986, Font 1987, La Violette et al. 1990) and plays a major role in determining the circulation pattern in the northern part of the region, occasionally altering the hydrodynamic conditions prevailing there. The most important influx of fresh- water run-off in the south comes from the Ebro River. Current flow in the region is southwesterly along the edge of the continental shelf. Associated with this current is a typical shelf-slope front separating less saline inshore waters from the waters of the open sea (Font et al. 1988), though the front may exhibit considerable spatio-temporal instability (Wang et al. 1988). Font et al. (1990) described the intrusion of water from the slope onto the shelf caused by the sudden broadening of the shelf north of the Ebro River delta, which is a source of permanent upwelling in that area. The formation of instabilities in the shelf-slope front may be related to shelf structure and plays an important role in shelf-slope water exchange (Tintoré et al. 1990).

\section{MATERIAL AND METHODS}

Sampling area. A total of 11 anchovy egg and larval cruises were carried out off Catalonia between latitudes $40^{\circ} 12^{\prime} \mathrm{N}$ and $42^{\circ} 24^{\prime} \mathrm{N}$ (Cape Creus - Ebro River delta) between 1983 and 1985. Table 1 presents a summary of the sampling cruises carried out during these $3 \mathrm{yr}$.

Sampling was performed using a grid of stations used throughout over the $3 \mathrm{yr}$ sampling period. The grid basically comprised 39 stations, though on certain surveys this number was increased (Fig. 1). Stations were arranged along 17 transects perpendicular to the

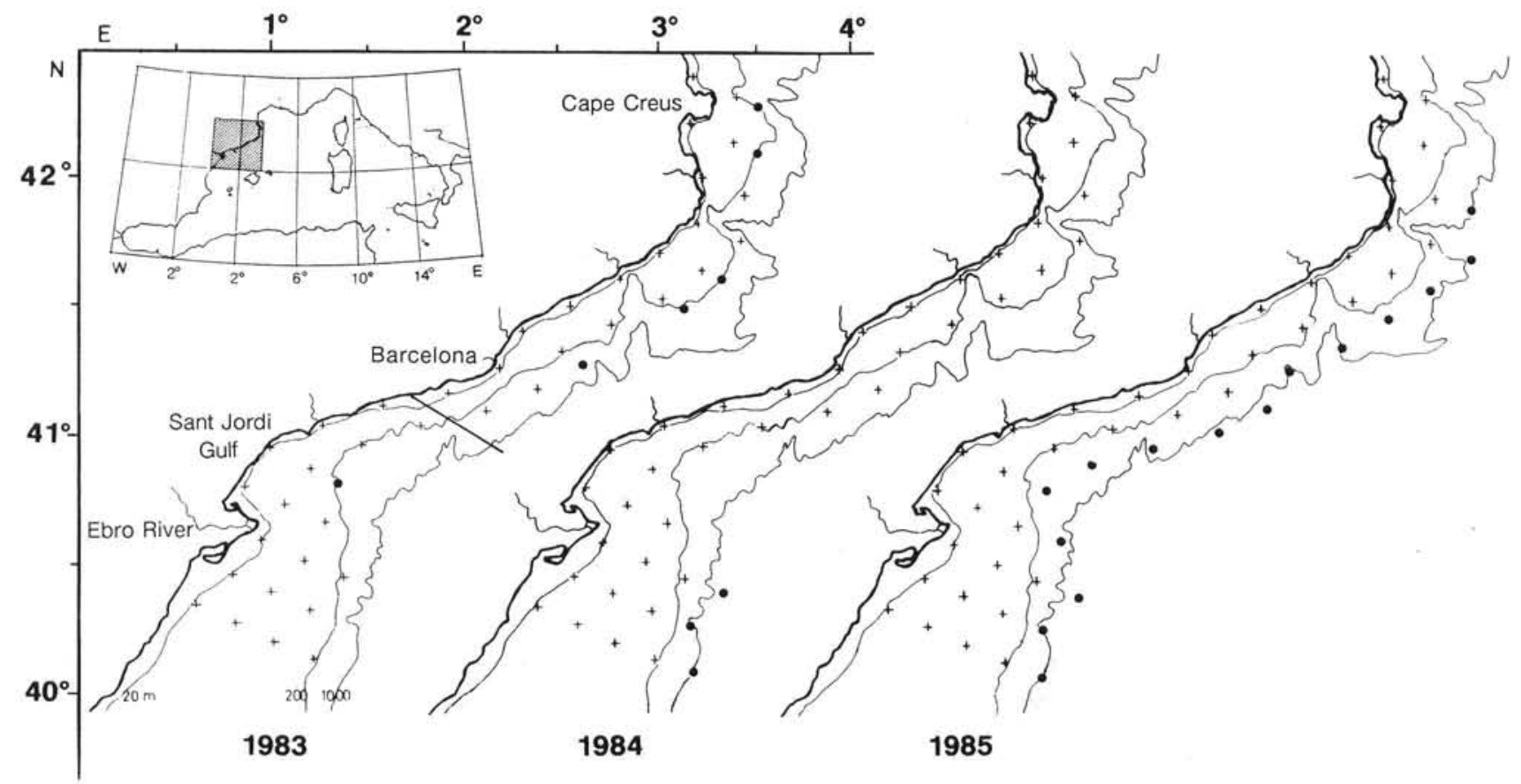

Fig. 1. Study area and sampling stations. (+) Stations sampled during all $3 \mathrm{yr}$ of the study period; $(\bullet)$ new stations sampled when the basic station grid was extended 
Table 1. Engraulis encrasicolus. Summary of anchovy egg abundance cruises carried out off the Catalonian coast between 1983 and 1985. Positive stations $=$ eggs present

\begin{tabular}{|c|c|c|c|c|c|}
\hline \multirow[t]{2}{*}{ Cruise dates } & \multirow{2}{*}{$\begin{array}{c}\text { Cruise } \\
\text { area }\left(\mathrm{km}^{2}\right)\end{array}$} & \multirow{2}{*}{$\begin{array}{l}\text { No. of } \\
\text { stations }\end{array}$} & \multirow{2}{*}{$\begin{array}{l}\text { No. of positive } \\
\text { stations }\end{array}$} & \multicolumn{2}{|c|}{ Mean abundance (no. $10 \mathrm{~m}^{-2}$ ) } \\
\hline & & & & All stations & Positive stations \\
\hline 14-26 Apr 1983 & 12246 & 45 & 12 & 56.1 & 205.9 \\
\hline 14-20 May 1983 & 12246 & 45 & 36 & 815.6 & 1019.5 \\
\hline 8-12 Jun 1983 & 12246 & 45 & 42 & 2135.4 & 2234.8 \\
\hline 19-25 Jul 1983 & 12246 & 45 & 36 & 951.1 & 1188.9 \\
\hline 7-14 Sep 1983 & 12246 & 45 & 16 & 29.4 & 82.8 \\
\hline $4-10$ Oct 1983 & 12246 & 45 & 7 & 3.8 & 24.8 \\
\hline 27 Apr-3 May 1984 & 11814 & 39 & 15 & 53.4 & 148.8 \\
\hline 16-21 Jun 1984 & 10487 & 35 & 32 & 755.8 & 826.7 \\
\hline 17-22 Aug 1984 & 12831 & 42 & 24 & 125.4 & 219.5 \\
\hline 30 Sep-5 Oct 1984 & 12175 & 40 & 5 & 3.2 & 9.2 \\
\hline 12-20 Jun 1985 & 17118 & 54 & 40 & 420.9 & 572.0 \\
\hline
\end{tabular}

coast. The distance between stations on a given transect and between transects was 10 miles. This strategy was designed so that most stations were located over the shelf between the 15 and $200 \mathrm{~m}$ isobaths, because the literature up to the time consistently supported the idea of inshore spawning over bottom depths of less than $200 \mathrm{~m}$. Since the shelf is quite narrow in certain spots, some stations were located over the slope.

Oblique tows with a $40 \mathrm{~cm}$ bongo net were carried out at each station from $200 \mathrm{~m}$, or from just above the bottom, to the surface. Vessel speed was 2 knots and the retrieval speed was 10 or $20 \mathrm{~m} \mathrm{~min}^{-1}$. The bongos were fitted with 300 and $500 \mu \mathrm{m}$ mesh nets and flowmeters.

The number of eggs in each sample was standardized to the number under $10 \mathrm{~m}^{2}$ of sea surface (Smith \& Richardson 1979). Census estimates of the total number of anchovy eggs in the area covered by the surveys and of seasonal egg production were calculated according to the method described by Houde (1977), which assumes constant production over the entire spawning season:

$$
P_{\mathrm{a}}=\sum_{i=1}^{r} \frac{P_{i} \times D_{i}}{d_{i}}
$$

where $P_{\mathrm{a}}=$ total number of eggs spawned in an annual spawning season; $P_{i}=$ total number of eggs estimated in the area covered by Cruise $i ; D_{i}=$ duration (in days) of Cruise $i ; d_{i}=$ time in days from spawning to hatching based on the results of Regner (1985) and estimated as $4 \mathrm{~d}$ at 13 to $14^{\circ} \mathrm{C}, 3 \mathrm{~d}$ at 15 to $17^{\circ} \mathrm{C}$ and $2 \mathrm{~d}$ at 18 to $22^{\circ} \mathrm{C}$, applying the temperature readings made on each survey; and $r=$ number of cruises in a season.

Hydrographic sampling (i.e. water temperature and salinity) was performed using a Neil Brown CTD on 5 of the cruises and using Niskin bottles fitted with inversion thermometers on the remaining cruises.
Results on the vertical distribution of anchovy eggs have indicated a distribution confined to above the thermocline (Palomera 1991), and these results were taken into account in designing the analysis of the temperature at which spawning took place. Mean temperature was calculated at the different sampling intervals in the upper $50 \mathrm{~m}$ during months of vertical mixing (April to May) and above the thermocline in those months in which a thermocline was present (June to October).

\section{RESULTS}

\section{Spatio-temporal distribution}

Anchovy eggs were present on all the cruises, that is, from April to October, and were most abundant from May to July (Table 1). Figs. 2 to 4 indicate the distribution of anchovy eggs in the different months.

Spawning commenced in the second half of April off the Ebro River delta as only anchovy eggs, but no larvae, (Palomera \& Sabatés 1990) were found during surveys carried out in late April 1983 and 1984. In the rest of the region, however, neither eggs nor larvae appeared until May. This agrees with the findings of Palomera \& Rubiés (1979) for an annual sampling cycle conducted off Barcelona, in which anchovy larvae were recorded only from May onwards. Spawning duration also varied from north to south: off the Ebro River delta, though the presence of eggs was sporadic and egg abundance was low, eggs were collected until October in both 1983 and 1984, whereas in the rest of the region eggs were collected on the October cruise only at a single station in 1983. Larval abundance in October was also very low, a further indication that spawning was drawing to an end (Palomera \& Sabatés 1990). 

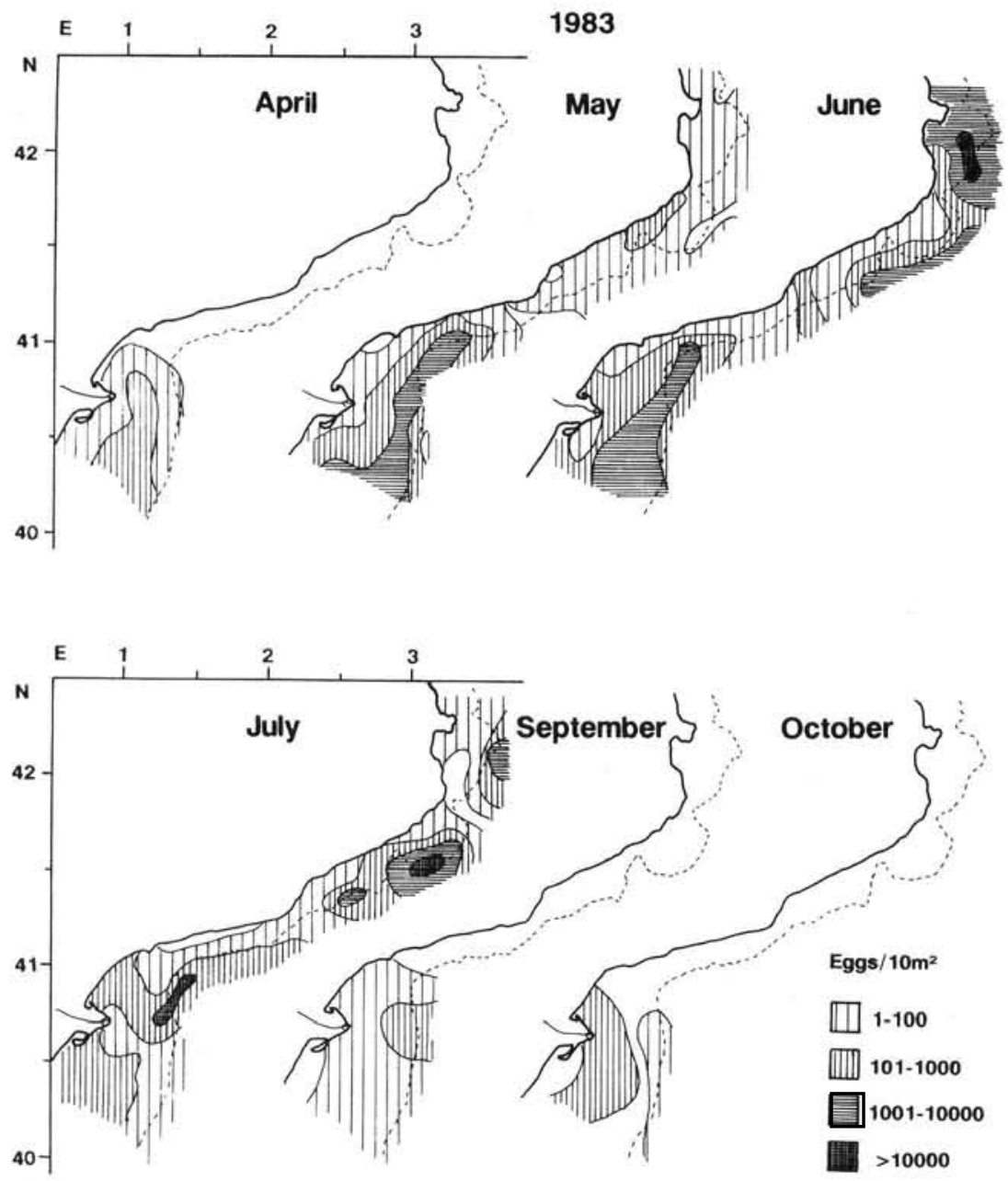

Fig. 2. Engraulis encrasicolus. Distribution and abundance of anchovy eggs during the 1983 spawning season

Fig. 5 depicts the spatio-temporal distribution of eggs along the coast over the 6 mo sampling period carried out in 1983. Mean abundance values along the 6 northernmost transects indicated a short spawning season (May to July-August?), with a peak in June and July that accounted for $98 \%$ of total spawning. Spawning was also short in the area covered by the central transects, abundance was considerably lower, and spawning was concentrated in May $(45 \%)$ and June-July ( $55 \%$ ). In the southern region, in the vicinity of the Sant Jordi Gulf and the Ebro River delta, spawning peaked in May and June; these months accounted for $86 \%$ of spawning, though, as already pointed out above, spawning went on until October.

Mean abundance on the 11 surveys ranged from 3.2 to 2135.4 anchovy eggs per $10 \mathrm{~m}^{2}$ of sea surface (Table 1). The highest values of all surveys, more than 10000 eggs per $10 \mathrm{~m}^{2}$ of sea surface, were recorded at 3 stations near the shelf edge in the northern part of the region in June and July 1983 (Fig. 2). There were clear differences in abundance between 1983 and 1984 (Table 1, Figs. $2 \& 3$ ), when spawning was poorer and values higher than 1000 eggs per $10 \mathrm{~m}^{2}$ of sea surface were recorded at only a few stations. The study area was extended in June 1985 (Fig. 1), when peak spawning had been recorded in the previous $2 \mathrm{yr}$, in an effort to determine the full offshore extent of spawning. No eggs were collected at $66 \%$ of the extra stations added, and eggs were present only at some of the new stations located over the narrow portion of the shelf, where spawning occurred in all 3 sampling years, though abundance values were very low (12 to 28 eggs $10 \mathrm{~m}^{-2}$ ).

The main spawning areas in the northern and southern parts of the region also exhibited differences. The surveys were designed to cover the continental shelf, which is wider in the southern part of the region. Peak spawning in the south was located mainly between 20 and 30 miles offshore. In the northern part of the region, however, high spawning abundance values were concentrated between 10 and 20 miles offshore, even on the June 1985 survey, on which sampling was extended further offshore (Figs. 2, 3, \& 4). The difference in the distance from the coast in these 

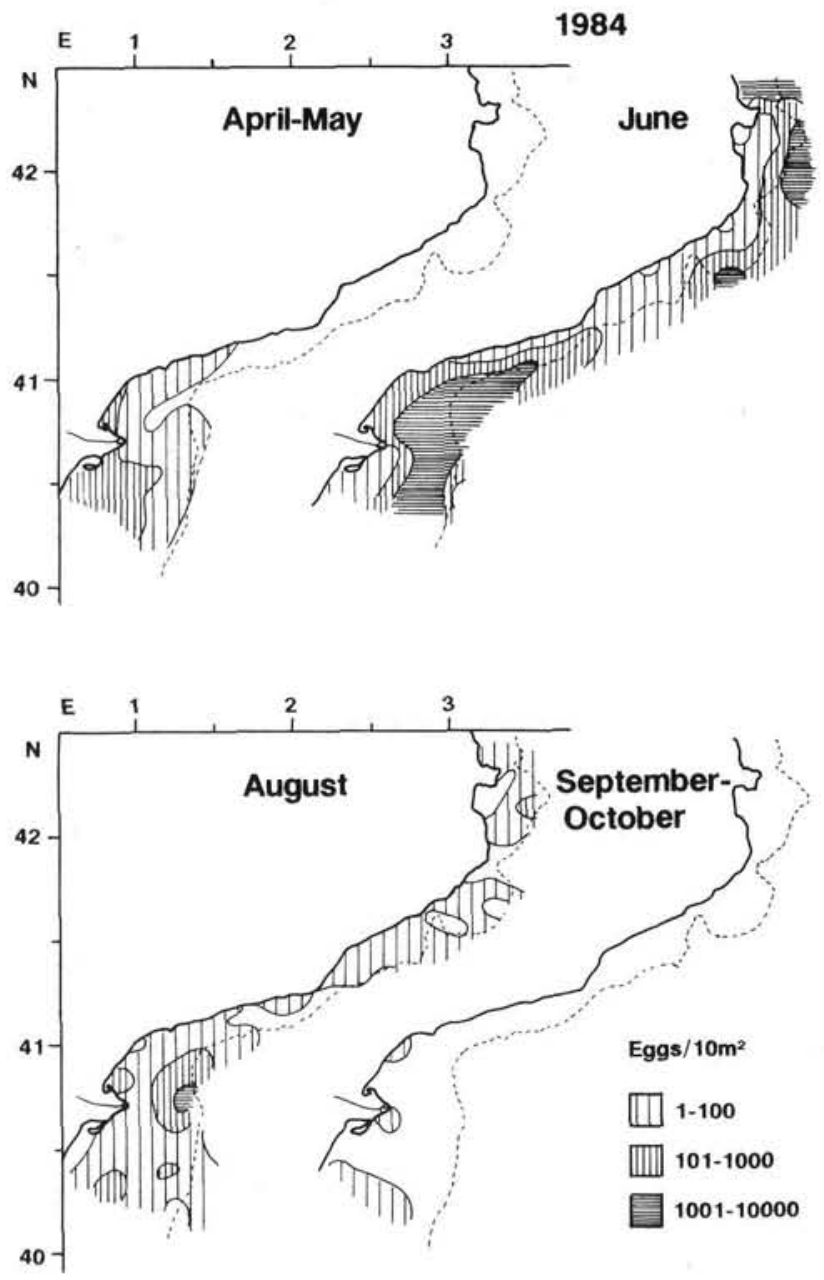

Fig. 3. Engraulis encrasicolus. Distribution and abundance of anchovy eggs during the 1984 spawning season

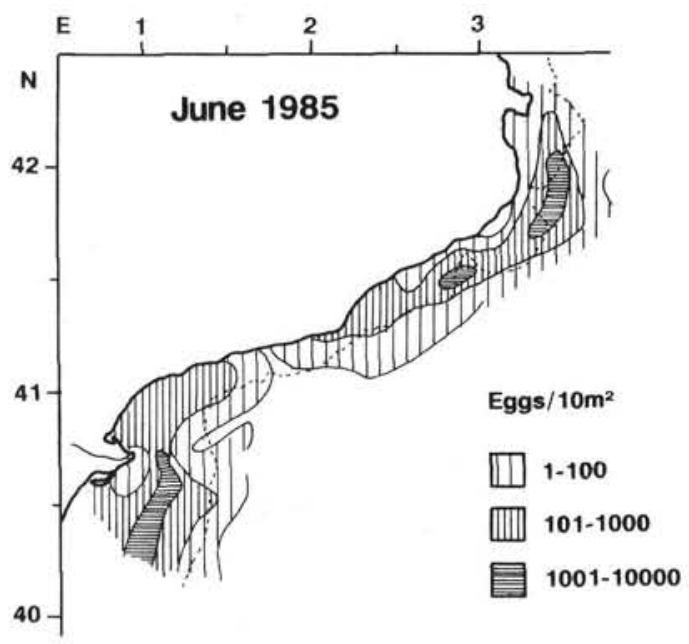

Fig. 4. Engraulis encrasicolus. Distribution and abundance of anchovy eggs in June 1985

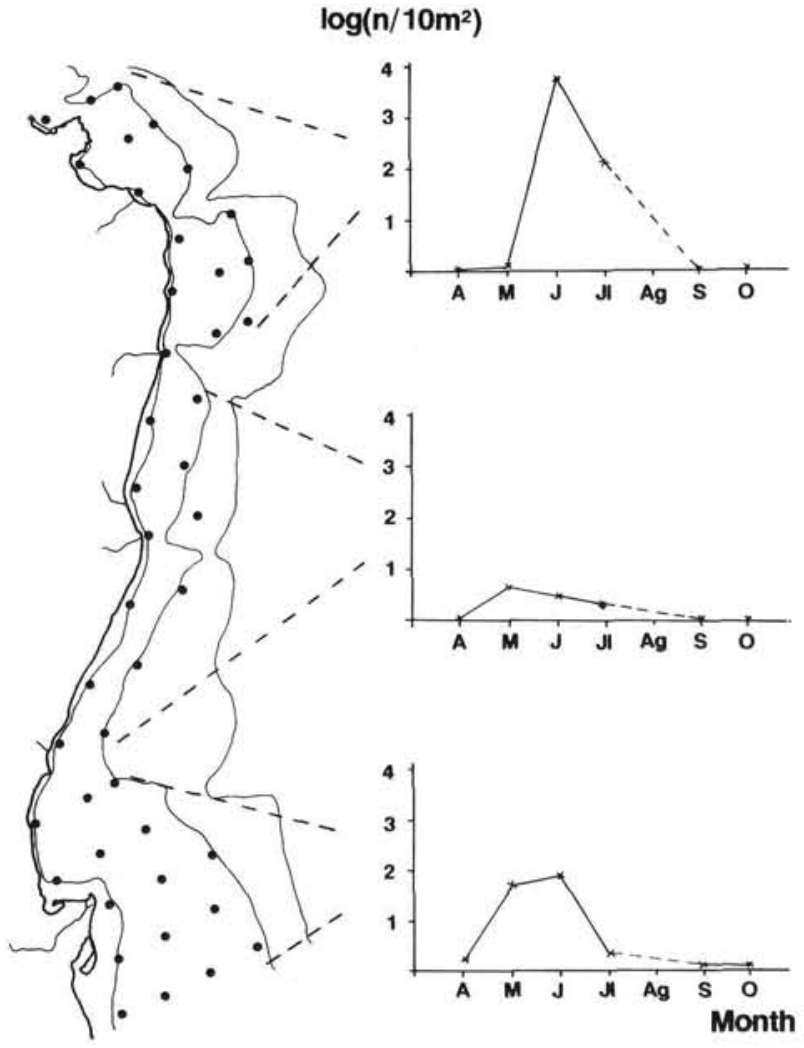

Fig. 5. Engraulis encrasicolus. Spatio-temporal distribution of anchovy eggs off the Catalonian coast in 1983. $\mathrm{n}=$ mean egg abundance

2 areas was thus clearly related to the location of the shelf break and the slope. This suggests that the largest aggregations of spawning adults form near the edge of the shelf.

\section{Egg production}

Table 2 presents monthly estimates of anchovy egg abundance for the entire spawning period in 1983. The estimates were calculated more as a means of comparing production in the 2 spawning areas than as an assessment of annual spawning. The 2 different areas considered in the region are separated in Fig. 1 by a line drawn perpendicular to the coast off Barcelona; the northern part of the region represented an area $5627 \mathrm{~km}^{2}$, the southern part of the region $6184 \mathrm{~km}^{2}$.

Egg production off Catalonia during the spawning season attained the highest values in the northern part of the region in June and July. The highest value in the southern part of the region was recorded in June; though close, this value was nonetheless lower than the values in the north. The lowest production rates were recorded in the south in October. 
Table 2. Engraulis encrasicolus. Monthly and total egg production in the northern and southern study areas in $1983 . D_{i}=$ duration of Cruise $i$ in days

\begin{tabular}{|c|c|c|c|c|c|c|}
\hline \multirow[b]{2}{*}{ Month } & \multicolumn{3}{|c|}{ Northern area } & \multicolumn{3}{|c|}{ Southern area } \\
\hline & $D_{i}$ & $\begin{array}{c}\text { Egg } \\
\text { abundance }\end{array}$ & $\begin{array}{l}\text { Egg } \\
\text { production }\end{array}$ & $D_{i}$ & $\left(\times 10^{9}\right)$ & $\begin{array}{l}\text { Egg } \\
\text { production }\end{array}$ \\
\hline April & 18 & 0 & 0 & 18 & 84.1 & 378.6 \\
\hline May & 28 & 25.5 & 238.3 & 26 & 1179.4 & 10221.1 \\
\hline June & 32 & 1351.6 & 21626.3 & 32 & 1130.3 & 18084.5 \\
\hline July & 47 & 970.3 & 22803.1 & 45 & 203.7 & 4582.8 \\
\hline September & 38 & 0 & 0 & 41 & 43.5 & 891.7 \\
\hline October & 12 & 0 & 0 & 17 & 5.5 & 46.6 \\
\hline Annual total $\left(P_{\mathrm{a}}\right)$ & & & 44667.7 & & & 34205.3 \\
\hline
\end{tabular}

\section{Relationship between spawning and the environment}

Studies carried out to date have indicated that temperature is the main factor regulating the onset of spawning in anchovy (Furnestin \& Furnestin 1959) and that the minimum temperature is approximately $13^{\circ} \mathrm{C}$ (Fage 1920), with spawning intensifying as the temperature rises. In the Mediterranean, Aldebert \& Tournier (1971) found that spawning commenced in the Golfe du Lion when the water temperature reached 14 to $15^{\circ} \mathrm{C}$, and Regner (1985) found anchovy eggs in the Adriatic from 13 to $15^{\circ} \mathrm{C}$.

For the study area as a whole, the water temperature at which anchovy eggs were collected ranged from 13.0 to $25.5^{\circ} \mathrm{C}$ (Fig. 6). The temperature range in the north was the same as in the rest of the region, with eggs present in May from $13.5^{\circ} \mathrm{C}$, and $73 \%$ of positive stations recorded at temperatures between 15.0 and $20.0^{\circ} \mathrm{C}$. In the south eggs appeared in April at temperatures between 13 and $13.5^{\circ} \mathrm{C}$ on various occasions, but, unlike in the northern part of the region, the range of temperatures over which eggs were collected was wider, with $70 \%$ of positive stations recorded at temperatures between 14.0 and $22.0^{\circ} \mathrm{C}$. The difference in the duration of spawning between the 2 areas would seem to be related to a decrease in temperature. In September 1983 the surface temperature in the northern area had fallen to about $2{ }^{\circ} \mathrm{C}$ below the temperature recorded in July (Fig. 7), coinciding with the end of spawning in the area; this temperature was sustained through the month of October. In contrast, in the southern area, the temperature decrease was not as great $\left(1{ }^{\circ} \mathrm{C}\right.$ in September), and the temperature was still higher than the temperature in the north in July; spawning went on, though egg abundance was lower.

Turning to the relationship between spawning and salinity, anchovy is a species that is able to tolerate a broad range of salinities (Reid 1967), and eggs have been found at salinity levels between 17 and $40 \%$

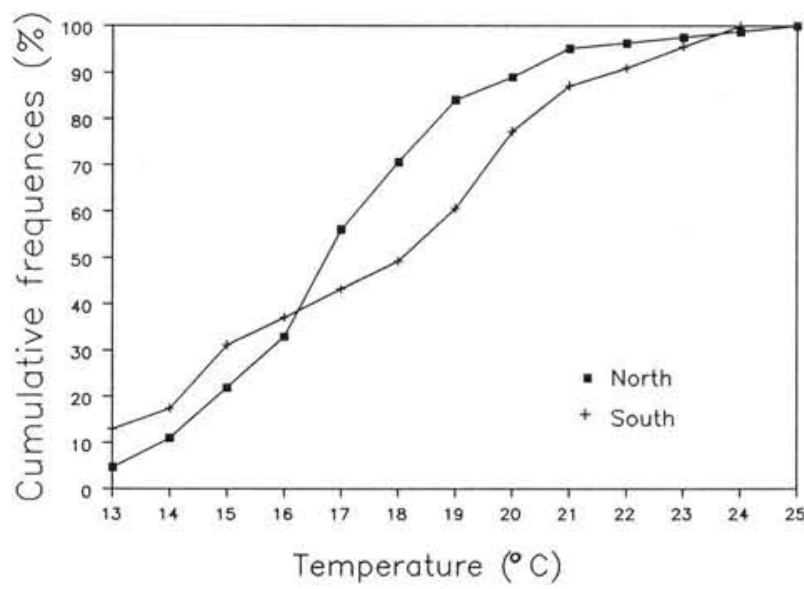

Fig. 6. Engraulis encrasicolus. Cumulative anchovy egg frequencies over the temperature range recorded in all months in which spawning took place during the $3 \mathrm{yr}$ sampling period in the northern and southern parts of the study area

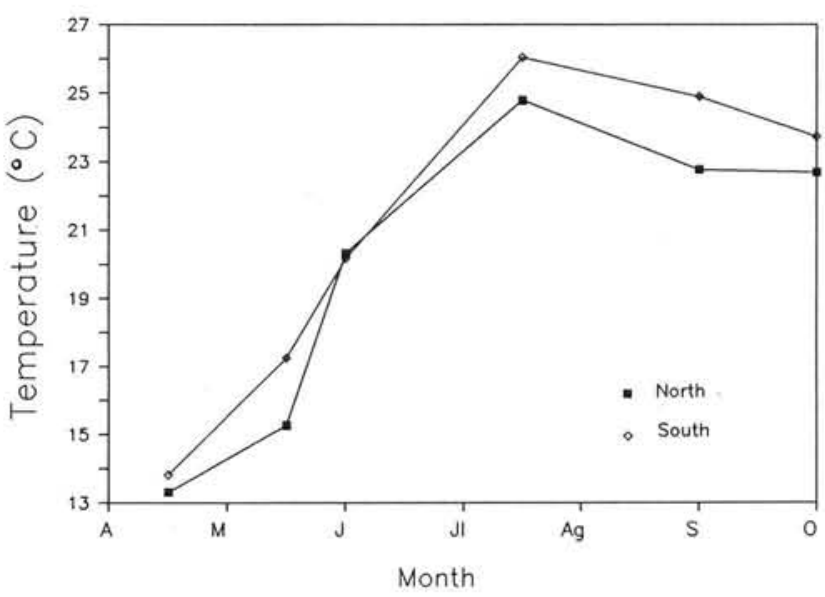

Fig. 7. Engraulis encrasicolus. Monthly mean surface temperatures in northern and southern parts of the study area during the 1983 sampling period 
(Demir 1968). Thus, the salinity range recorded in the study area, 29.1 to $38.2 \%$ (Masó \& Duarte 1989), would not act as a factor limiting the spawning of this species. Nevertheless, in June 1983 a plume of fresh water (salinities of 29 to $31 \%$ ) from the Rhône River was detected at the surface in the northern part of the study area (Castellón et al. 1986), and it was associated with a large spawning area in which the highest values of anchovy egg abundance were recorded at the time. This might indicate a preference of anchovy for lower salinities, although the author believes that it is more closely related to a shift in the area of anchovy distribution southward from the Golfe du Lion in order to spawn. Adults were thus probably taking advantage of the optimum feeding conditions associated with the plume of fresh water, since phytoplankton production was higher there, as evidenced by high chlorophyll values (Masó \& Duarte 1989).

\section{DISCUSSION}

Earlier studies of the spawning season of anchovy in the Western Mediterranean (D'Ancona 1931, Fage 1935, Demir 1965) and more specifically off the coast of Spain (Andreu \& Rodríguez Roda 1951, Planas \& Vives 1951, Palomera \& Rubiés 1979) agreed that the species basically spawns from April to September. The results of the present study provide conclusive evidence of latitudinal differences in the duration of the spawning period off the coast of Catalonia associated with local temperature fluctuations.

Despite the difference in the duration of the spawning period, total egg production (Table 2) was similar in both spawning areas and in fact even somewhat higher in the northern area where the cycle was shorter. Since the spawning period was mainly limited to $2 \mathrm{mo}$, this means that spawning intensity was commensurately higher. In the northern part of the region, anchovy seemed to spawn at the time of year when water temperature was high and the outflow from the Rhône River was still substantial (Tintoré et al. 1990), creating, in terms of stability and productivity, an environment favourable to spawning. Richardson (1981) reported similar spawning behaviour for the northern subpopulation of Engraulis mordax $\left(40\right.$ to $\left.50^{\circ} \mathrm{N}\right)$, which spawns during June and July, while the central subpopulation ( 30 to $40^{\circ} \mathrm{N}$ ) spawns practically all year long. Coinciding with our observations, Parrish et al. (1983) suggested that the northern anchovy subpopulation spawning is related to the combination of greater stability in weather conditions and enrichment phenomena, in this case the influx of inland waters. Hence it appears that individual stocks have adapted their spawning strategy to a short spawning period to ensure greater egg and larval survival. The findings on larval mortality published by Palomera \& Lleonart (1989), who reported lower mortality of anchovy larvae in the northern part of the region, would seem to bear this out. Furthermore, Alheit et al. (1983) for E. ringens and Laroche \& Richardson (1980) for E. mordax pointed out that relative fecundity appeared to vary with latitude, and they concluded that anchovies at higher latitudes may attain higher fecundity levels. Such variability might be the cause underlying the differences in egg production observed for E. encrasicolus in our region, although the hypothesis of higher batch fecundity in the northern part of the region requires further substantiation.

Based on the peak spawning (i.e. egg abundance) recorded, previous studies have suggested that adults of Engraulis encrasicolus spawned over a specific range of bottom depths. Off the Atlantic coast of Morocco, Furnestin \& Furnestin (1959) reported that peak spawning of anchovy occurred over bottom depths ranging between 25 and $100 \mathrm{~m}$, with a maximum at $50 \mathrm{~m}$, though never close inshore, while during the rest of the year shoals of adult anchovy were located over deeper depths $(200 \mathrm{~m})$ at the edge of the continental shelf. Aldebert \& Tournier (1971) recorded peak spawning in the Golfe du Lion between the 60 and $120 \mathrm{~m}$ isobaths, contrasting with very low abundance levels inshore. Off Catalonia the depth range would thus seem to be much broader and less welldefined than in the previous cases, though here again spawning did not take place inshore. The egg distribution charts, particularly for the periods of peak spawning, clearly show the most important spawning areas where abundance values were highest to be located relatively far from shore.

Considering bottom topography in the region, with large variations in shelf width, spawning peaks did not seem to be related to an attempt by adults to seek a particular range of bottom depths for spawning. The highest abundance levels (>1000 eggs $10 \mathrm{~m}^{-2}$ ) were generally recorded from 10 to 30 miles offshore, which in this region spans a very broad range of bottom depths, from 50 to $1000 \mathrm{~m}$. The presence of the shelf-slope front, which, subject to certain fluctuations in intensity, runs along the entire shelf (Font et al. 1988), suggests that anchovy may take advantage of the productivity associated with the front, particularly bearing in mind the substantial enrichment associated with the front during the peak spawning period (summer) (Estrada \& Margalef 1988). Sabatés (1990a) pointed out the important role of this frontal zone in the spawning and aggregation of larvae of a number of fish species.

Spawning was clearly associated with 2 areas under the influence of the inflows of 2 large rivers, i.e. the Rhône and the Ebro Rivers. A similar association has 
also been reported for anchovy in the Bay of Biscay in the vicinity of the mouth of the Loire River (Arbault \& Lacroix 1977). The importance of the influx of inland waters from the Golfe du Lion became apparent in June 1983, when the highest levels of anchovy eggs and larvae were recorded in the zone covered by the surface plume of fresh water in the northern part of the region, whereas the larvae of most other fish species were located at the outer edges of this plume (Sabatés 1990b). Moreover, in the vicinity of the Ebro River delta the highest concentrations of anchovy eggs were recorded in the permanent upwelling zone described by Font et al. (1990), caused by the intrusion of slope waters onto the continental shelf.

The association of spawning by pelagic species with regions of high production, such as eastern boundary currents (Peru; California; Canary; Benguela) has been widely documented in recent years. The areas of maximum spawning by certain pelagic species, like anchovy and sardine in the North Pacific and anchovy off Namibia, are located near thermal fronts (O'Toole 1977, Lasker et al. 1981). Parrish et al, (1983) described some common environmental patterns that influence the spawning strategies of anchovys and sardine in these regions. However, no evidence of this type of behaviour had previously been reported for Engraulis encrasicolus, especially in the Mediterranean, where the hydrographic processes that underlie enrichment phenomena are smaller in scale than those active in other areas where similar linkages between spawning and environment take place.

Acknowledgements, I thank all participants on the sampling cruises for their collaboration in samples collection. I particularly thank Ms B. Moli, L. Recasens, S. Verón and Dr A. Sabatés for their assistance in sorting the material examined. Drs P. Olivar, A. Sabatés, Messrs. P. Rubiés and J. Salat made valuable comments on the original manuscript. Mr R. Sacks prepared the English version. The study was supported by a grant from the Fundación Ramón Areces.

\section{LITERATURE CITED}

Aldebert, Y., Tournier, H. (1971). La reproduction de la sardine et de l'anchois dans le golfe du Lion. Rev. Trav. Inst. Pêch. Marit. 35(1): 57-75

Alheit, J., Alegre, B., Alarcon, V. H., Macewicz, B. (1983). Batch fecundity and spawning frequency of various anchovy (Genus: Engraulis) populations from upwelling areas and their use for spawning biomass estimates. F.A.O. Fish. Rep. 291: 977-985

Andreu, B., Rodríguez Roda, A. (1951). La pesca marítima en Castellón. Rendimiento por unidad de esfuerzo (19451949) y consideraciones biométricas de las especies de interés comercial. Publnes Inst. Biol. apl, Barcelona 8: 233-277

Arbault, S., Lacroix-Boutin, N. (1977). Oeufs et larves de Clupeides et Engraulides dans le Golfe de Gascogne (1969-1973). Distribution des frayeres. Relations entre les facteurs du milieu et la reproduction. Rev. Trav. Inst. Pêch. Marit. 41(3): 227-254

Bas, C., Morales, E. (1954). Algunos datos para el estudio de la biología de la anchoa Engraulis encrasicolus de la costa Brava. Publnes Inst. Biol. apl., Barcelona 16: 53-70

Blaxter J. H. S., Hunter, J. R. (1982). The biology of clupeoid fishes. Adv, mar. Biol. 20: 1-223

Castellón, A., Masó, M., Salat, J. (1986). Some observations on Rhone fresh water plume in the Catalan coast. Rapp. P.-v. Réun Commn int. Explor. scient. Mer Méditerr. 29: $1-3$

D'Ancona, U. (1931). Famiglia Engraulidae. In: Bardi, G., Friedlander, R. (eds.) Uova, larve e stadi giovanili di Teleostei. Fauna e Flora del Golfo di Napoli, Monogr. 38, p. $16-20$

Demir, N. (1965). Synopsis of biological data on anchovy Engraulis encrasicolus (Linnaeus) 1758 (Mediterranean and adjacent seas). FAO Fish. Synopses 26(1): 1-42

Demir, N. (1968). Analysis of local populations of the anchovy Engraulis encrasicolus (L.), in Turkish waters based on meristic characters. Rev. Fac. Scien. Univ. Istanbul, ser. B, t. $33(1-2): 25-57$

Estrada, M., Margalef, R. (1988). Supply of nutrients to the Mediterranean photic zone along a persistent front. In: Minas, H. J., Nival, P. (eds.) Oceanographie pelágique méditerranéene, Oceanol. Acta, Special Issue 9: 133-142

Fage, L. (1920). Engraulidae, Clupeidae. Rep. Dan. Oceanogr. Exped. Mediterr. 2(A9): 1-140

Fage, L. (1935). La ponte et les races locales de l'anchois de la Mediterranée (Engraulis encrasicolus L.). Rapp. P.-v. Réun Commn int. Explor. scient. Mer Mediterr, 10: 67-71

Font, J. (1987). The path of the Levantine Intermediate Water to the Alboran sea. Deep Sea Res. 34(10): 1745-1755

Font, J., Salat, J., Tintoré, J. (1988). Permanent features in the circulation of the Catalan sea. In: Minas, H. J., Nival, P. (eds.) Oceanographie pelágique méditerranéene, Oceanol. Acta, Special Issue 9: 51-57

Font, J., Juliá, A., Rovira, J., Salat, J., Sánchez-Pardo, J. (1990). Circulación marina en la plataforma continental del Ebro determinada a partir de la distribución de masas de agua y los microcontaminantes orgánicos en el sedimento. Acta Geol. Hisp. 21/22: 483-489

Furnestin, J., Furnestin, M. L. (1959). La reproduction de la sardine et de l'anchois des côtes atlantiques de Maroc (saisons et aires de ponte). Rev. Trav. Inst. Péch. Marit. 23(1): 79-104

Houde, E. D. (1977). Abundance and potential yield of the round herring, Etrumeus teres, and aspects of the early life history in the eastern Gulf of Mexico. Fish. Bull. U.S. 75(1): $61-89$

Laroche, J. L., Richardson, S. (1980). Reproduction of northern anchovy Engraulis mordax off Oregon and Washington. Fish. Bull. U.S. 78: 603-618

Larrañeta, M. G., (1981). La pesquería de sardina, Sardina pilchardus (Walb.) de Castellón. Investigación pesq. 45(1): 47-92

Lasker, R., Pelaez, J., Laurs, R. M. (1981). The use of satellite infrared imagery for describing ocean processes in relation to spawning of the northern anchovy (Engraulis mordax). Remote Sensing Environ. 11: 439-453

La Violette, P. E., Tintoré, J., Font, J. (1990). The surface circulation of the Balearic Sea. J. geophys. Res. 95: $1559-1568$

Masó, M., Duarte, C. (1989). The spatial and temporal structure of hydrographic and phytoplankton biomass heterogeneity along the Catalan coast (NW Mediterranean). J. mar. Res. 47: 813-827 
Motos, L., Santiago, J. (1990). An egg production estimate of biomass of the Bay of Biscay anchovy (Engraulis encrasicolus L.) in 1989. Comm. Meet. int. Coun. Explor. Sea C.M.-ICES/H: 26: 1-27

O'Toole, M. J. (1977). Investigations into the early life history of the South West African anchovy Engraulis capensis Gilchrist. Ph.D. thesis, University of Capetown

Palomera, I. (1991). Vertical distribution of anchovy eggs and larvae in stratified waters of the Western Mediterranean. Mar. Biol. 111(1): 37-44

Palomera, I., Lleonart, J. (1989). Field mortality estimates of anchovy larvae, Engraulis encrasicolus, in the western Mediterranean. J. Fish Biol. 35 (Suppl. A): 133-138

Palomera, I., Rubiés, P. (1979). Ichthyoplankton de la mer Catalane. Larves de poissons recoltées sur des stations fixes devant Barcelone au cours d'un cycle annuel (19751976). Rapp. P.-v. Réun Commn. int. Explor. Scient. Mer Mediterr. 25/26: 201-206

Palomera, I., Sabatés, A. (1990). Co-occurrence of Engraulis encrasicolus and Sardinella aurita eggs and larvae in the western Mediterranean. Scientia Marina 54(1): 61-67

Parrish, R. H., Bakun, A., Husby, D. M., Nelson, C. S. (1983). Comparative climatology of selected environmental processes in relation to eastern boundary current pelagic fish reproduction. F.A.O. Fish. Rep. 291: 731-778

Planas, A., Vives, F. (1951). Sobre la puesta de la anchoa Engraulis encrasicolus L. in el Levante español. Publ. Inst. Biol. apl., Barcelona 9: 119-130

Ré, P. (1987). Ecology of the planktonic phase of the anchovy Engraulis encrasicolus (Linnaeus) 1758, within Mira

This article was submitted to the editor
Estuary (Portugal). Investigación pesq. 51: 581-598

Regner, S. (1985). Ecology of planktonic stages of the anchovy, Engraulis encrasicolus (Linnaeus, 1758), in the central Adriatic. Acta Adriat. 26(1): 1-113

Reid, J. L. (1967). Oceanic environments of the genus Engraulis around the world. Calif. coop. oceanic Fish Invest. Rep. 11: $26-33$

Richardson, S. L. (1981). Spawning biomass and the early life of northern anchovy, Engraulis mordax, in the northern subpopulation off Oregon and Washington. Fish. Bull. U.S. 78(4): 855-876

Sabatés, A. (1990a). Distribution pattern of larval fish populations in the Northwestern Mediterranean. Mar. Ecol. Prog. Ser. 59: 75-82

Sabatés, A., (1990b). Changes in the heterogeneity of mesoscale distribution patterns of larval fish associated with a shallow coastal haline front. Estuar. coast. Shelf Sci. 30: 131-140

Smith, P. E., Richardson, S. L. (1979). Standard techniques for pelagic fish egg and larva surveys. F.A.O. Fish. tech. Pap. No. 175,107 pp.

Suau, P. (1979). Biología del boqueron (Engraulis encrasicolus L.) de las costas de Castellón (E de Espana). Investigación Pesq. 43: 601-610

Tintoré, J., Wang, D. P., La Violette, P. E. (1990). Eddies and thermohaline intrusions on the shelf/slope front off the NE Spain coast. J. geophys. Res. 95: 1627-1634

Wang, D. P., Vieira, M. E. C., Salat, J., Tintoré, J. (1988). A shelf slope filament off the northeast Spanish coast. J. mar. Res, 46: 321-332

Manuscript first received: April 30, 1991

Revised version accepted: December 16, 1991 